\title{
Assessing and Predicting Changes in the Status of Gambari Forest Reserve, Nigeria Using Remote Sensing and GIS Techniques
}

\author{
Oludare H. Adedeji ${ }^{*}$, Opeyemi 0. Tope-Ajayi1 ${ }^{1}$, Olukemi L. Abegunde² \\ ${ }^{1}$ Department of Environmental Management and Toxicology, Federal University of Agriculture, \\ Abeokuta, Nigeria \\ ${ }^{2}$ National Centre for Remote Sensing, Jos, Plateau State, Nigeria \\ Email: ${ }^{*}$ hakeemdare1222@yahoo.co.uk
}

Received 27 April 2015; accepted 25 June 2015; published 30 June 2015

Copyright (C) 2015 by authors and Scientific Research Publishing Inc.

This work is licensed under the Creative Commons Attribution International License (CC BY).

http://creativecommons.org/licenses/by/4.0/

(c) (i) Open Access

\section{Abstract}

Rapid population growth and increasing economic activities have resulted in unsustainable exploitation and rapid decline in the spatial extent of forest reserves in Nigeria. Studying land use dynamics of these forest reserves is essential for analysing various ecological and developmental consequences over time. Land use/land cover mapping, change detection and prediction are essential for decision-making and implementing appropriate policy responses relating to land uses. This paper aims at assessing and predicting changes in land use/land cover at Gambari forest reserve, Nigeria using remote sensing and GIS techniques. The study determined the magnitude, rate and dynamics of change in the spatial extent of the forest reserve between 1984 and 2014 using multi-temporal datasets (Landsat TM 1984 and 2000 and OLI/TIRS 2014). The imageries were classified using ArcGIS 10.0 version with support of ground truth data and Land use Change Modeller (LCM) and Markovian processes were employed to analyse the pattern and trend of change. Prediction of 2044 scenario carried out using neural network, which is a built-in module in the Idrisi. The study revealed dramatic decline in the extent of the forest reserve as both the plantation of exotic tree species (Tectona grandis and Gmelina) and the indigenous stands have been logged in several places for timber and to make way for cultivation of crops. In addition, pressures from other land uses like settlements have also led to increased non-forest uses particularly bare grounds. The study concluded that increasing loss of the indigenous forest and plantation would continue thus having implications for biodiversity conservation in the study area. There is the need for participation of different stakeholders and sectors to solve conflicting demands on limited forest resources and ensure ecosystem integrity.

${ }^{*}$ Corresponding author.

How to cite this paper: Adedeji, O.H., Tope-Ajayi, O.O. and Abegunde, O.L. (2015) Assessing and Predicting Changes in the Status of Gambari Forest Reserve, Nigeria Using Remote Sensing and GIS Techniques. Journal of Geographic Information System, 7, 301-318. http://dx.doi.org/10.4236/igis.2015.73024 


\title{
Keywords
}

\author{
Change Detection, GIS, Gambari Forest Reserve, Forest Degradation, Idrisi, LCM, Satellite Remote \\ Sensing
}

\section{Introduction}

Tropical forests are the richest and the most diverse ecosystem on earth but are unsustainably over exploited despite legislation to control their exploitation [1] [2]. FAO [3] revealed that ninety percent of the original moist forest in West Africa is gone and the leftover is heavily fragmented and degraded, while in Nigeria, Federal Environmental Protection Agency [4] showed that over 43\% of the total geographic area of 923,768 $\mathrm{km}^{2}$ has been lost in 12 years to human activities [5]. The threat to the rainforest compelled the establishment of forest reserves with the introduction of exotic tree species in the 1960s. Nigeria has 1160 constituted forest reserves covering a total land area of 10,752,702 hectares and this represents about $10 \%$ of the total land area [6]. Exotic tree species such as teak (Tectona grandis) and Gmelina were established in the forest reserves by the Federal and State governments in conjunction with the World Bank to provide raw materials and products in the form of poles, timber, veneer, wood particles, pit props, pulp, fuelwood and for research [7] [8]. However, as far back as thirty-one years ago, observation of tree population in a permanent sample plots in the forest reserves, for example the Gambari Forest Reserve located close to Ibadan, southwest Nigeria revealed that there was consistent decline in the number of trees per hectare [9]. In fact, FAO report on the rate of deforestation in Nigeria that between 1990 and 2010, Nigeria lost an average of 409,650 ha or 2.38\% per year [10]. Presently, satellite imageries have shown serious deforestation and degradation of the Gambari Forest Reserve like many other reserves in the country due to the expansion of agriculture, fire, grazing, natural mortality, bush burning and more importantly indiscriminate exploitation of timber by illegal fellers [11] [12]. Adedeji [13] observed that the dereservation of forest reserves and poor forest management practices in the Gambari Forest Reserve among other were responsible for some of the indiscriminate exploitation of tree species at alarming rates. Forests are multifunctional ecosystems providing material and intangible services as carbon sinks, enhanced regional biodiversity, environmental services, forest-based economies [15], and functions to living organisms, hence their losses are taken seriously [11] [14]. Loss of forest resources poses a significant threat to the achievement of Millennium Development Goals due to decline in ecosystem health [16] [17]. In view of the steady and rapid decline of the natural and plantation forest and the attendant environmental and health problems, it is essential that this landchange dynamic be appropriately monitored and analyzed.

Despite the importance of vegetation mapping as one of the basic components of ecological database of any region, Adejuwon [18] lamented that vegetation has continued to be inaccurately mapped in Nigeria. Furthermore, most decisions about how much land to use were and for what purposes (and the related consequences) are still poorly understood [19]. Therefore, there is an urgent need for proper geo-management of land and the concomitant availability of a detailed, accurate and up-to-date geo-information [20]. Understanding the dynamics of forest loss is critical for the planning and protection of biodiversity [21] [22]. Insights into patterns, rates, and trends of landscape changes are necessary to realize forest dynamics, enable preservation, and evaluate the effectiveness of management approaches [22] [23]. Land cover changes may result from human-induced land use changes or natural processes, i.e. climatic variability and natural disturbances [24]. Recent advances have demonstrated the feasibility of using coarse spatial resolution remote sensing imagery to assess tropical forest over large areas [25]-[27]. Remotely sensed data have in the past four decades steadily become invaluable information source for ecological characterization and survey [28]. This is due to the effectiveness of air-borne and space-borne remote sensing platforms and sensors that facilitate observation of biophysical attributes over extensive areas at multiple spatial, spectral and temporal scales [29]. Studying the dynamics of land cover requires maps that reflect the status of land cover at different times [30]. Land cover and land use changes are recognized as main agents of global change via their interactions with climate, ecosystem processes, biogeochemical cycles, biodiversity and human activities [31]. Change detection is the concept of identifying contrasts or discrepancies in the state of an object or phenomenon by observing it at different times [32]. Change detection studies are centred on identifying the biotic and abiotic components of the spectral and temporal changes 
that are occurring within ecosystems [33]. It involves the ability to quantify temporal alteration and transformation using multi-temporal data sets. Detecting, describing and understanding such changes are of considerable interest, not only to ecologists or environmental conservationists, but also to resource managers [34]. In fact, understanding of land cover change especially in relation to the forest is a pressing need for sustainable development because these changes can lead to land use conflicts due to the need for resources and space and the capacity of the land to absorb and support these needs [35]. Land-cover mapping determines the current composition and distribution of landscape attributes, and this is subsequently used as the basis for assessing future change [36]-[39]. Satellite remote sensing is an important source of data source for monitoring, detection, quantification, and mapping of forest cover patterns and changes, because of its repetitive data acquisition, digital format appropriate for computer processing, and accurate georeferencing approaches [40]-[44]. The advent of geographic information system (GIS) has made it possible to integrate multisource and multidate data for the generation of land use and land cover changes involving such information as the trend, rate, nature, location and magnitude of the changes [45]. However, there is a general lack of accurate and current LULC maps in Nigeria, especially concerning forest and other natural resources [46]. The aim of this study is to assess and predict in changes in status of Gambari forest reserve, Nigeria using remote sensing and GIS techniques. It also model future change in the area using Markov Chain Modeller in Idrisi [47].

\section{Methodology}

\subsection{Study Area}

The Gambari Forest Reserve (Figure 1) is classified as IUCN category IV reserve. It was declared to be Ibadan

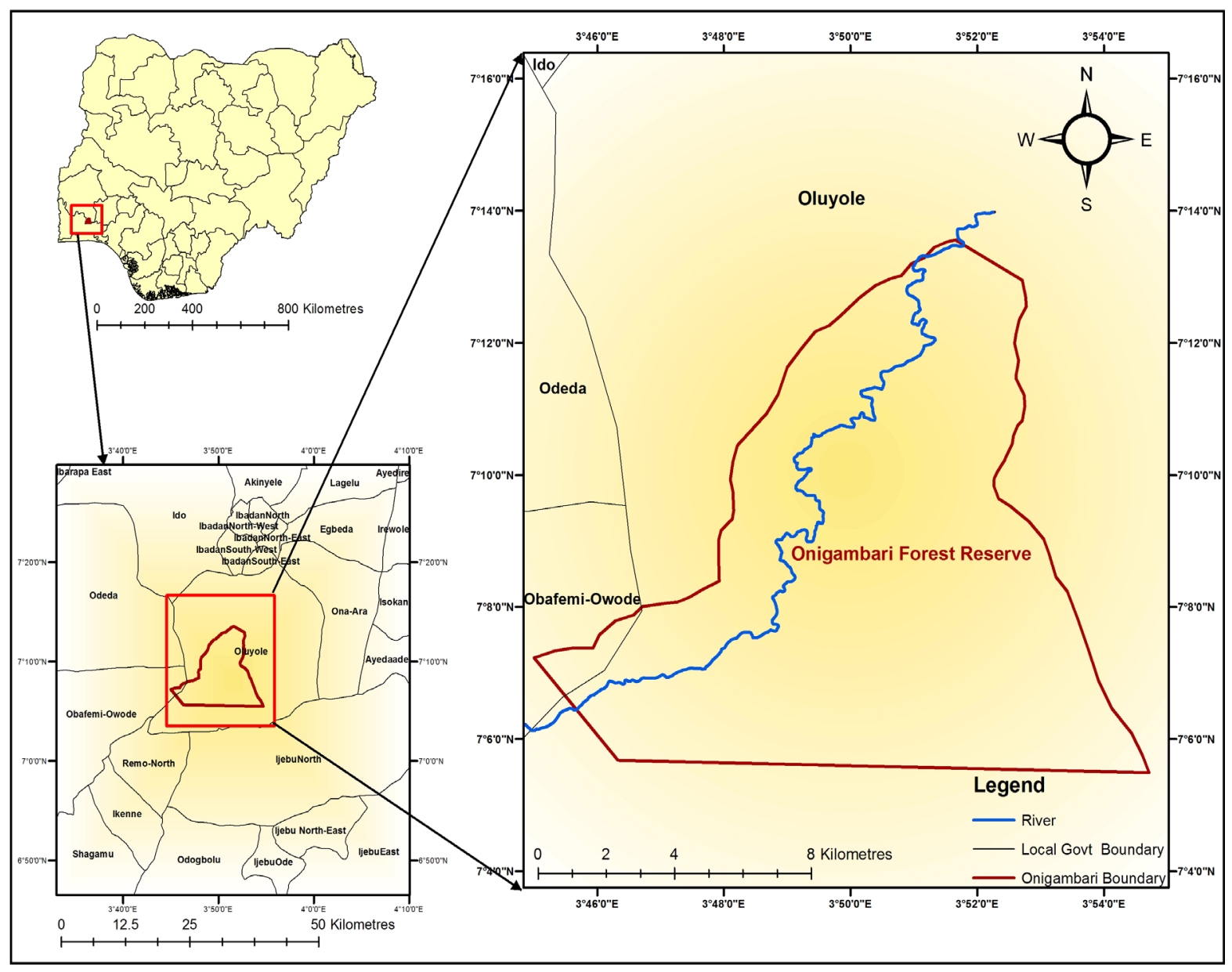

Figure 1. Gambari forest reserve, Nigeria. 
forest reserve by a resolution of the then Ibadan council on 14th September 1899 [48] and take its name from a nearby village called Onigambari. The reserve is located on latitude $7^{\circ} 25^{\prime}$ and $7^{\circ} 55^{\prime} \mathrm{N}$ and longitude $3^{\circ} 53^{\prime}$ and $3^{\circ} 9^{\prime} \mathrm{E}$. The forest reserve, which used to be part of the lowland rainforest, is now in the Guinea savanna and Derived savanna zones [11]. It covers a total land area of 13932.18 hectares consisting of five zones: Mamu, Onigambari, Busogboro, Odo-Ona/Onipe and Olonde [49]. The Mamu and Onigambari zones were predominantly made up of Gmelina plantations. The topography is generally undulating, lying at altitude between $120-150 \mathrm{~m}$ above sea level and the area is bounded by two Rivers (Rivers Ona and Awon). Mean annual rainfall ranges between $1200 \mathrm{~mm}$ to $1300 \mathrm{~mm}$ with two distinct wet seasons, May-July and September-November and a short dry period in August. The major dry season occurs between December and March. Temperatures are high throughout the year with a mean annual value of about $27^{\circ} \mathrm{C}$ and an annual range of $30^{\circ} \mathrm{C}$ [50]. Monthly relative humidity at $0900 \mathrm{hr}$ GMT is more than 80 per cent, and at $1500 \mathrm{hr}$, the value fluctuates between 60 and 80 per cent except during January and February when it drops below 60 per cent [51]. The soil is generally brown sandy loam and described as having a depth of $45 \mathrm{~cm}$ with overlaying clay and iron stone gravel-soil that is about $1.21 \mathrm{~m}$ deep but varies from place to place and grouped as an Alfisols [52]. It is derived from the basement complex of metamorphic and granite rocks with intrusions of quartzite, schists, gneisses and iron concretions [53]. The clay mineral is kaolinite. Soil pH is about 6.5 - 7.0 which tends to rise with accumulation of litter. A large part of the original natural rainforest consisting of indigenous species such as Terminalia spp, Triplochiton scleroxylon, Irvingia garbonensis, and Treculia africana were cleared and replanted with exotic tree species of Gmelina arborea and Tectona grandis [54]. The natural and plantation forests presently lay side-by-side in the area.

\subsection{Data Acquisition and Processing of Images}

The images used in this study were downloaded from the official website of Global Land Cover Facility (GLCF) - (http://www.glcf.umiacs.umd.edu). Detailed characteristics of the sources of data used for the study are shown in Table 1.

Landsat TM for 1984 and 2000 and Operational Land Imager/Thermal Infrared Sensor (OLI/TIRS) 2014 images were employed in the study (Table 1). The three scenes corresponded with path 191 and row 055 of the WRS-2 (Worldwide Reference System). The scenes were cloud-free and had good radiometric quality as reported by the data provider. The scenes were the best available satellite images for the study period. The imageries were processed in the Geographic Information System (GIS) environment. Image pre-processing including geometric, atmospheric and topographic corrections were carried out to ensure spatial and temporal comparability of the datasets [55]. The three sets of images were first geo-corrected and geo-referenced because effective image processing is critical to successful urban land use/land cover mapping and change detection [56]. Image pre-processing allow for conformity between multi-temporal imagery necessary for quantification and spatial comparisons [57]. The 2000 image was used as the base image for geometrical correction due to its better visual quality. Geometric correction of the 2000 scene was based on Ground Control Points (GCPs) identified on the topographical maps of the area. The 1984 and 2014 scenes were co-registered to the base image using additional GCPs into UTM projection with geometric errors of less than one pixel, so that all the images have the same coordinate system. Image enhancement method was carried out using the histogram equalization and the differences in the pixels are compensated for to produce uniformly distributed pixels along the output axis [58]. The preparation and cropping of the images to cover the specified area required was achieved using subset prepared using Erdas Imagine 10.0 software. Ground truth information were collected and combined with the images to assess the accuracy of image classification. All data were developed into Universal Transverse Mercator (UTM) coordinate system, zone 31, with World Geocoded System (UTM WGS 84) projection parameters. Figure 2

Table 1. Characteristics of the Landsat images used in the study.

\begin{tabular}{cccc}
\hline Sensor & Date of Acquisition & Spatial Resolution(m) & Path/Row \\
\hline Landsat TM & $1984 / 04 / 18$ & $30 \mathrm{~m}$ & $191 / 055$ \\
Landsat TM & $2000 / 02 / 06$ & $30 \mathrm{~m}$ & $191 / 055$ \\
Landsat OLITIRS & $2014 / 12 / 07$ & $30 \mathrm{~m}$ & $191 / 055$ \\
\hline
\end{tabular}




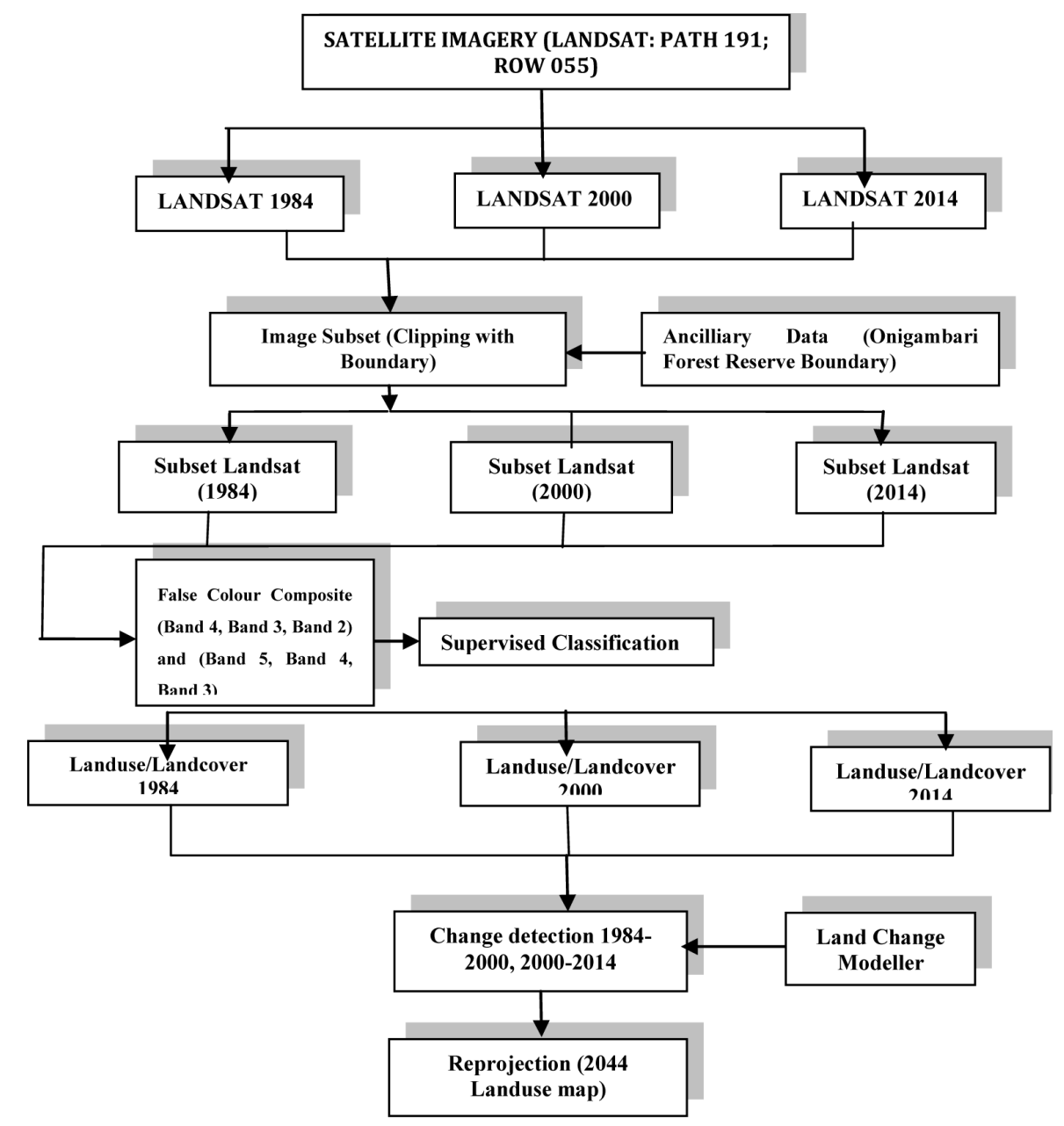

Figure 2. Flowchart of methodology in the study.

shows the Flowchart of methodology of the study.

To map land use/land cover types as well as to analyse land use changes in the Gambari Forest Reserve overtime, false colour composite (FCC) images of Landsat-TM (1984, 2000) and Landsat-OLI/TIRS data (2014), were made and processed using ArcMap 10.0 software. On the images, water bodies appeared dark as it would absorb all the wavelengths, bare soil and bare rock surfaces appeared green, vegetation (forests and cultivated land) showed up in red and settlements and roads showed up in shades of cyan. A false colour composite from Landsat-TM uses an RGB combination of band 4 representing the NIR infrared, band 3 belongs to red and band 2 to green while in Landsat-OLI/TIRS uses an RGB combination of band 5 representing the NIR infrared, band 4 belongs to red and band 3 to green (Figure 3 ).

\subsection{Image Classification}

Image Classification is a process of categorising an image into a fewer number of individual classes, based on the reflectance values [59]. The goal of image classification is to extract landscape information from the satellite images [60]. Jensen [61] have discussed in detail the fundamental elements of image interpretation including grayscale tone, colour , height and depth, size, shape, texture, pattern shadow, site, association and arrangement. Image classification refers to the extraction of differentiated land cover and land use categories classes from raw remotely sensed digital satellite data [62]. The imageries were classified based on sample set created according to training samples. Training samples are representative of the desired land use classes [63] and were determined based on ground truthing, researcher's personal experience and physiographical knowledge of the study area [61]. 


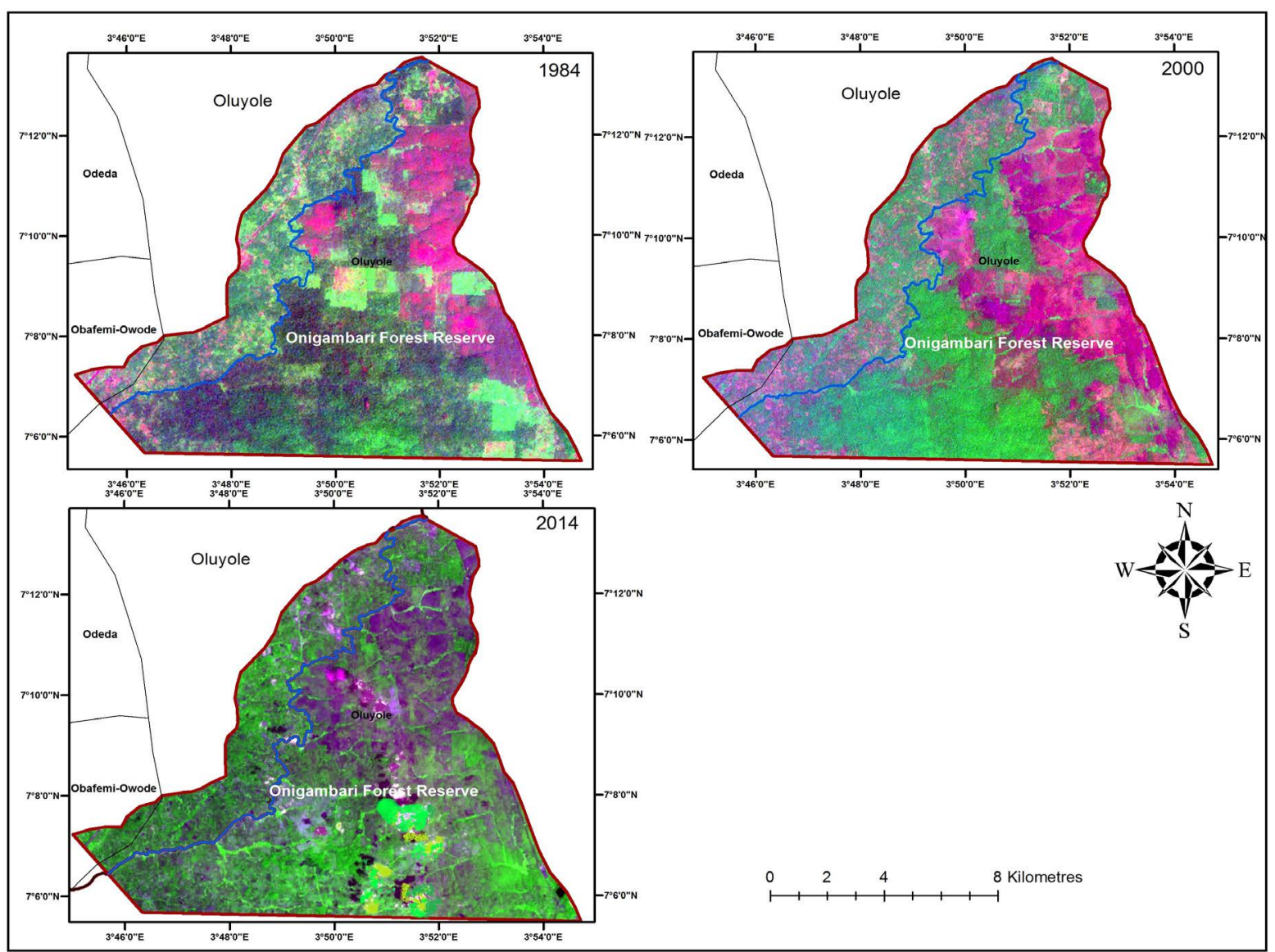

Figure 3. False Colour Composite (FCC) of satellite imageries of Gambari Forest Reserve for 1984, 2000, and 2014.

Twenty (20) training samples were collected for each Landsat imagery and the Maximum Likelihood Classifier [64] was used in performing supervised classification in the GIS environment using ArcGIS 10.0 software. This procedure has proven to be a robust and consistent classifier for multi-date classifications [65]. The classified land use images of Gambari forest reserve for 1984, 2000 and 2014 were vectorised to show discrete land use types as units on the land use/land cover maps that depict predominant land cover type within relatively homogeneous areas in the study area. The land cover classes are important to make the classification easier [66]. Land cover classes adopted in the study were based on the classes proposed by the Coordination of Information on the Environment (CORINE). CORINE land cover is a map of the European environmental landscape based on interpretation of satellite images. It gives useful geo-referenced information for disaggregation [67]. The Level 1 classification system was followed and the data was classified into four land use/land cover classes spread over the study area. The classes are shown in Table 2.

A post-classification processing was applied using ancillary data to discriminate between forests and timber plantations as well as other land cover classes. Change trajectory of post classification comparison was used to map the patterns and extents of land use and land cover in the forest reserve as well as determine the magnitude of changes between the years of interest, 1984, 2000 and 2014, respectively. The classified images of different periods were then superimposed in GIS environment with the objective of filling a matrix showing transitions between the classified land use/cover categories. The evolving land use/land cover types were quantified using cross tabulation statistics to carry out land use/land cover change.

\subsection{Accuracy Assessment of the Image}

It is important to evaluate the accuracy of classification results and for this confusion/error matrices were used. This is an important method for evaluating per-pixel classification [62]. Accuracy assessments of the classified 
Table 2. Description of major Land cover types defined in this study.

\begin{tabular}{cr}
\hline Land cover classes & Description \\
\hline Plantation & Timber plantations with Tectona arborea and Gmelina \\
Agricultural land use & Arable land, permanent crops, pastures and heterogeneous agricultural areas \\
Thick Forest & Indigenous species such as Terminalia spp, Triplochiton scleroxylon, Irvingia garbonensis, and Treculia africana. \\
Light Forest & Secondary forest, Shrubs and/or herbaceous vegetation association, \\
Bare ground & Permanently degraded land, bare ground, rock, quarry despoiled lands \\
\hline
\end{tabular}

images were assessed using the three multi-temporal images. Overall accuracy of 94.62\%) was achieved for the Landsat TM image of 1984, while overall accuracies of the Landsat TM of 2000 and Landsat OLI/TIRS of 2014 were $90.05 \%$ and $87.42 \%$ respectively. These indicated excellent overall classifications.

\subsection{Change Detection Analysis}

Change detection is defined as a process that is used to quantify the changes that are associated with land use and land cover in the landscape using geo-referenced multi-temporal remote sensing information [68]. To calculate the extent of each land cover class, we analysed classified maps using ArcGIS 10.0. Change detection analysis was carried out on Landsat images of different years (i.e. 1984, 2000 and 2014) to analyze the pattern and trend of change analysis in the study area using Land Change Modeller (LCM) for ecological sustainability and Markov chain model embedded in Idrisi [69]. Land Change Modeller is innovative land planning and decision support software, which allows rapid analysis of land cover change and simulate future land change scenarios [70]-[73]. The LCM relies on separate multi-temporal image classification and subsequent image comparison [63]-[64]. It is suited for analysis and prediction of LULC types and evaluation of implications of the changes on the entire ecosystem [69] [74]. LCM can be used to know detail spatial increase and loss, net change, net change drivers, tendencies of change and landscape prediction [75]. Furthermore, Change Analysis and Map Transition Option in LCM is a mapping tool to visualize the change that occurred from one land class all the other land classes [76] and predicting the course of change into the future. Using LCM requires mainly two time categorical maps and so the classified maps of 1984 (time-1) and 2014 (time-2) were used as inputs for the Change Analysis Tab of IDRISI. This enabled us to understand the gains and losses and the transition of areas among the land use/land cover classes; and to quantify the changes occurred from time-1 to time-2 [70]. Finally, pairs of LULC maps were overlaid to produce the LULC change map.

\subsection{Markov Chain Modelling}

A Markovian process is one in which the future state of a system can be modelled purely based on the immediately preceding state. Markovian chain analysis will describe land use change from one period to another and use this as the basis to project future changes. Modelling help to provide a better understanding of the factors that drive forest changes and generate future forest cover scenarios to support the design of policy responses [77]. Markov Chain helps to determines exactly how much land would be expected to transit from the later date to the predicted date based on a projection of the transition potentials into the future and creates a transition probabilities file [70]-[71] [78]. This is achieved by developing a transition probability matrix of land use change from time one to time two, which shows the nature of change while still serving as the basis for projecting to a later time period [70] [79]. The Markov chain projection model was implemented on two classified LULC maps of different times [80]. The first image (2000) as the earlier image and the second image (2014) as the latter image was inputted. The model according to Iacono et al. [80] is based on the assumption that a future state $(t 2)$ can be determined by its current state $(t 1)$. In LULC modelling, the process determines the $t 1$ to $t 2$ LULC distribution using a transition matrix. It is expressed as:

$$
v t 2=M \times v t 1
$$

where $v t 1$ is the LULC proportion vector input, $v t 2$ is the LULC proportional vector output and $M$ is the $\mathrm{m} \times \mathrm{m}$ transition matrix for the time difference $\Delta t=t 2-\mathrm{t} 1$. The transition probabilities file is a matrix that records the 
probability that each land cover category will change to every other category.

\subsection{Statistical Analysis}

Land cover maps were employed to quantity land cover changes between 2000 and 2014 according to MelendezPastor et al. [81]. Land cover change statistics were computed in two different ways: 1) as absolute percentage increments of the whole study area calculated by subtracting percentage areas among 2014 and 2000; and 2) as relative percentage increments from 2000 . The negative symbol in the statistics indicated a loss of surface. Both approaches provided complementary information.

\section{Results}

\subsection{Land Change Process}

Land cover change detected from comparison of CORINE Land Cover data for 1984, 2000 and 2014 showed that over the whole study period, forest cover in the Gambari reserve has decreased dramatically. The most extensive land cover class in 1984 was the thick forest, which occupied more than a half of the area, followed by the plantation of exotic trees such as teak and Gmelina. Within the sixteen tears from 1984 and 2000 land cover change dynamic was dominated by a considerable increase plantation and agricultural land use (Table 3). However, there was reduction in the extent of the plantation due to dereservation policies and illegal felling of trees in the reserve. The thick forest have drastically reduced from 7514.4 ha in 1984 to 2274.39 ha by 2014, while there was increase in bare ground from mere 139.42 ha in 1984 to 1673.1 ha as of 2014. This an indication of rapid deforestation and degradation of land in the forest reserve overtime.

Agriculture land use also declined from 3177.03 ha in 1984 to 1431.18 ha by 2014, as many farm were abandon after the decline in soil fertility due to long time of tillage. Increase in the bareground is also due to increasing quarrying activities in parts of the reserve, which despoil the lands.

\subsection{Land Use/Land Cover Matrix}

A cross-tabulation procedure between the classifications was processed with IDRISI Selva [82]; area change, gains, losses and persistence were calculated as proposed by Pontius et al. [83]. Systematic transitions among classes were calculated and examined through the off-diagonal entries of the cross-tabulation matrix. Table 4 shows the summary of the major land use /land cover conversion in the Gambari Forest Reserve that took place between1984 and 2000. The diagonal of the table shows the land use/land cover that remained unchanged during the period, which is a total area of 5203.5 ha. This represented about $37.34 \%$ of the study area.

Thick forest had the highest conversion of 2906.74 ha to cultivated land, representing $20.79 \%$ of the area. About 22.33 ha of the area formerly occupied by plantation representing $0.16 \%$ of the total area were laid bare due to removal of trees without replanting. The thick forest area observed further disturbances as 45.65 ha $(0.33 \%)$ and 372.57 (2.66\%) were converted to light forest and agricultural lands respectively during the two periods.

The area covered by plantations of exotic trees of teak and gmelina declined from 2566.53 ha in 1984 to

Table 3. Size and proportion of land cover classes from 1984-2014.

\begin{tabular}{|c|c|c|c|c|c|c|}
\hline \multirow{2}{*}{ Land cover types } & \multicolumn{2}{|c|}{ Area in 1984} & \multicolumn{2}{|c|}{ Area in 2000} & \multicolumn{2}{|c|}{ Area in 2014} \\
\hline & На & $\%$ & На & $\%$ & На & $\%$ \\
\hline Plantation & 2574.11 & 18.47 & 3524.85 & 25.30 & 2739.96 & 19.67 \\
\hline Thick forest & 7514.4 & 53.94 & 3762.90 & 27.01 & 2274.39 & 16.32 \\
\hline Light Forest & 527.22 & 3.78 & 1238.04 & 8.89 & 5813.55 & 41.73 \\
\hline Bare ground & 139.42 & 1.00 & 751.86 & 5.39 & 1673.10 & 12.01 \\
\hline Agricultural land use & 3177.03 & 22.81 & 4654.53 & 33.41 & 1431.18 & 10.27 \\
\hline Total & 13932.18 & 100 & 13932.18 & 100 & 13932.18 & 100 \\
\hline
\end{tabular}


Table 4. Land use/Land cover matrix of Gambari Forest Reserve between 1984 and 2000 (Hectares).

\begin{tabular}{|c|c|c|c|c|c|c|c|}
\hline & \multicolumn{7}{|c|}{2000} \\
\hline & Land uses & Plantation & Thick forest & Light Forest & Bare Ground & $\begin{array}{l}\text { Agricultural } \\
\text { Land use }\end{array}$ & Total Area (Ha) \\
\hline \multirow{6}{*}{1984} & Plantation & 1285.3 & 46.86 & 738.82 & 448.44 & 47.11 & 2566.53 \\
\hline & Thick forest & 563.78 & 3282.98 & 2906.74 & 295.33 & 480.04 & 7532.21 \\
\hline & Light Forest & 45.65 & 54.16 & 336.76 & 28.26 & 60.83 & 526.33 \\
\hline & Bare Ground & 22.33 & 0.97 & 40.85 & 43.69 & 3.89 & 111.73 \\
\hline & Agricultural Land & 372.57 & 382.33 & 1853.64 & 326.04 & 254.8 & 3195.38 \\
\hline & Total Area (Ha) & 2291.63 & 3767.31 & 5882.81 & 1143.76 & 846.67 & 13932.18 \\
\hline
\end{tabular}

Grey hade means permanence, underline indicate significant transition.

2291.63 ha in 2000. Further land use conversions were witnessed in the period between 2000 and 2014 as the thick forest correspondingly decreased from 3762.9 ha in 1984 to 2274.39 has in 2014 (Table 5). Within the 30 -year period, the forest was lost due to illegal logging and other land uses including land clearance for agriculture. Furthermore, 514.17 hectares (5.05\%) of the land used for cultivation as of 2000 became bare ground fourteen years later in 2014 due to inappropriate land management such as bushing burning, shifting cultivation, and land abandonment. The area degraded by various anthropogenic activities including farming and quarrying within the study area increased from 111.73 ha in 984 to 751.86 ha in 2000 and further to 1673.1 ha by 2014 . The structure of the vegetation in the Gambari Forest Reserve is rapidly changing because of human activities in all the zones making up the reserve. These activities including illegal logging, unsustainable agricultural practices (e.g. bush burning), and soil erosion are causing the loss of forest lands. Depletion of unreserved forests has resulted in the concentration of logging activities within the forest reserves by both local and foreign timber merchants in conjunction with corrupt forestry officers. In fact, Kio [84] indicated that for the former state of western Nigeria the areas outside forest reserves accounted for 52\% of the total timber volume output in 1960 and that this percentage was reduced to $16 \%$ five years later. Total area occupied by natural forest type in the Gambari forest reserve was about 38 percent [85]. Land cover maps were obtained from satellite imagery for 1984, 2000 and 2014 (Figure 2).

\section{Discussions and Interpretation}

Land use/land cover changes are critical issue that degrade biodiversity and create impact on human life [86]. It should be noted that great environmental consequences could result with the continuous decline in the forest resources with gradual reduction of biodiversity and landscape complexity and a higher vulnerability to natural hazards [87]. Major driver of land use change in the study area include increasing demand for timber products, proximity of the forest reserve to big cities such as Lagos and Ibadan where there is demand for timber for both local use and export. Accessibility to forest is another driver because the forest reserve is well linked with good and accessible roads.

\subsection{Gain and Losses between 1984 and 2000, 2000 and 2014}

Figure 5 and Figure 6 show the gain and losses in land use/ land cover that occurred in the forest reserve from 1984 to 2000 and 2000 to 2014. The green bars (right side) indicate the gain per class in hectares, while the left side define the loss of each class. In terms of absolute gain, the light forest gained much from the felling of trees in the thick forest which latter replanted or grow on its own.

The light forest had the highest amount of gains between 1984 and 2000 (5542 hectares) while about 4248 hectares of the thick forest were lost within the same period (Figure 4). Between 2000 and 2014 more of the thick forest were lost with increase in the amount of bare ground (1520 hectares).

Figure 7 shows the net changes in land use/land cover from 2000 to 2014, while Figure 8 shows the contributions to net changes of each land use categories between 1984 to 2000 and 2000 to 2014 .

The study also calculated the contributions of other categories to their net change (Figure 8). This showed which classes in the 1984 map were identified as thick forest, light forest, plantation, agricultural land use or 


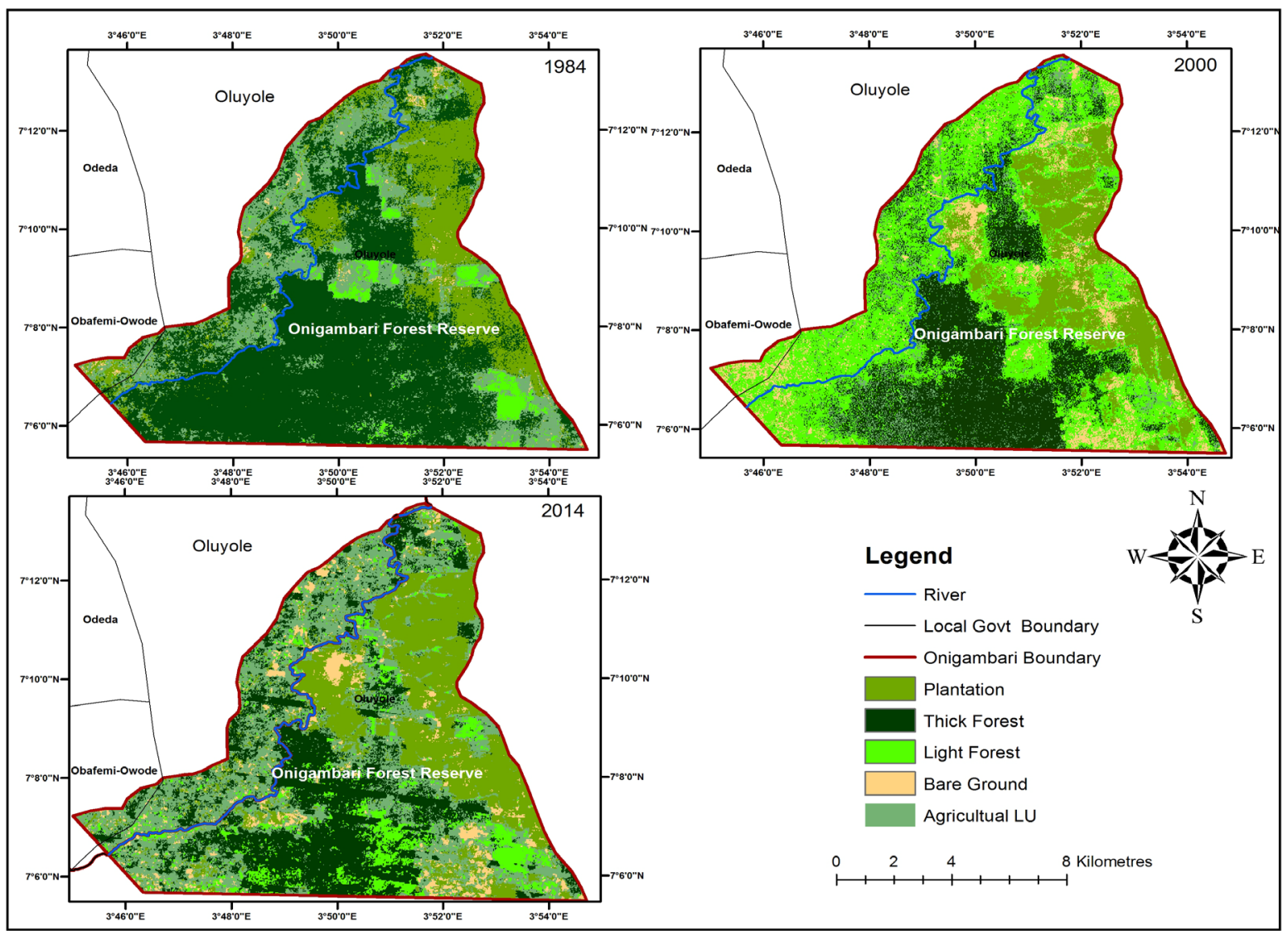

Figure 4. Classified satellite imageries of Gambari Forest Reserve for 1984, 2000, and 2014.

Table 5. Land use / Land cover matrix of Gambari Forest Reserve between 2000 and 2014 (Hectares).

\begin{tabular}{|c|c|c|c|c|c|c|c|}
\hline & \multicolumn{7}{|c|}{2014} \\
\hline & Land uses & Plantation & Thick forest & Light Forest & Bare Ground & $\begin{array}{l}\text { Agricultural } \\
\text { Land }\end{array}$ & Total Area (Ha) \\
\hline \multirow{6}{*}{2000} & Plantation & 1834.47 & 67.5 & 915.93 & 296.28 & 410.67 & 3524.85 \\
\hline & Thick forest & 224.82 & 987.57 & 1705.14 & 531.63 & 313.74 & 3762.9 \\
\hline & Light Forest & 61.83 & 218.43 & 702.09 & 178.29 & 77.40 & 1238.04 \\
\hline & Bare Ground & 146.79 & 40.59 & 279.27 & 152.73 & 132.48 & 751.86 \\
\hline & Agricultural Land & 472.05 & 960.3 & 2211.12 & 514.17 & 496.89 & 4654.53 \\
\hline & Total Area (Ha) & 2739.96 & 2274.39 & 5813.55 & 1673.1 & 1431.18 & 13932.18 \\
\hline
\end{tabular}

Grey shade means permanence, underline indicate significant transition.

bare ground in the 2000 map and what proportion of the total change for a class and proportion of the study area they explain. For instance light forest explain the majority of the total decrease in thick forest (2854 hectares), while losses in plantation, agricultural land use and thick forest explain the increase in the bare ground. Figure 9 show the major contributors to net changes in land use/land cover from 2000 to 2014. Forest recovery through succession was detected by the increase in the light forest after the thick forest was removed.

\subsection{Trends and Magnitude of Land Use Categories}

Table 6 provides information on the overall land cover changes between 2000 and 2014 based on the land cover 
Table 6. Land use/land covers change: Trend and Magnitude 2000 and 2014.

\begin{tabular}{ccccccc}
\hline \multirow{2}{*}{ Land cover classes } & \multicolumn{2}{c}{$\mathbf{2 0 0 0}$} & \multicolumn{2}{c}{$\mathbf{2 0 1 4}$} & \multicolumn{2}{c}{ 2000-2014 Changes } \\
\cline { 2 - 7 } & Ha & \% & Ha & \% & $\begin{array}{c}\text { Absolute increment } \\
\text { (\%) }\end{array}$ & $\begin{array}{c}\text { Relative increment } \\
\text { since 2000 (\%) }\end{array}$ \\
\hline Plantation & 3524.85 & 25.30 & 2739.96 & 19.67 & -5.63 & -22.25 \\
Thick Forest & 3762.90 & 27.01 & 2274.39 & 16.32 & -10.69 & -37.58 \\
Light Forest & 1238.04 & 8.89 & 5813.55 & 41.71 & 32.82 & 369.18 \\
Bare Ground & 751.86 & 5.39 & 1673.10 & 12.03 & 6.64 & 123.19 \\
Agricultural LU & 4654.53 & 33.41 & 1431.18 & 10.27 & -23.14 & -69.26 \\
Total & $\mathbf{1 3 9 3 2 . 1 8}$ & $\mathbf{1 0 0}$ & $\mathbf{1 3 9 3 2 . 1 8}$ & $\mathbf{1 0 0}$ & Not Applicable & Not Applicable \\
\hline
\end{tabular}

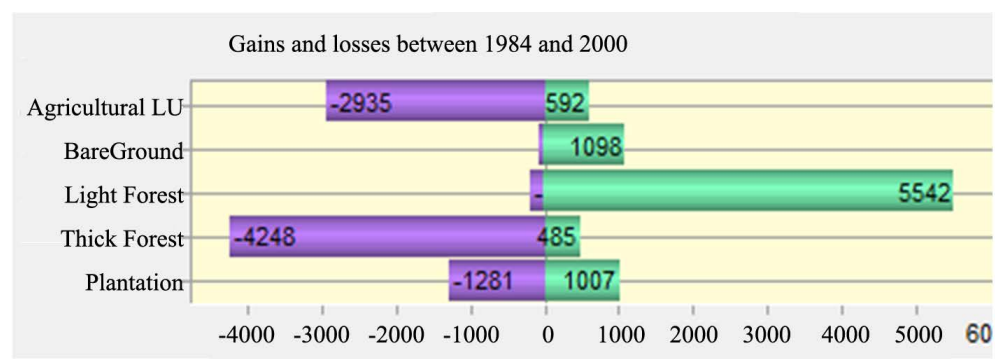

Figure 5. Gain and losses (Ha) in land use/land cover from 1984 to 2014.

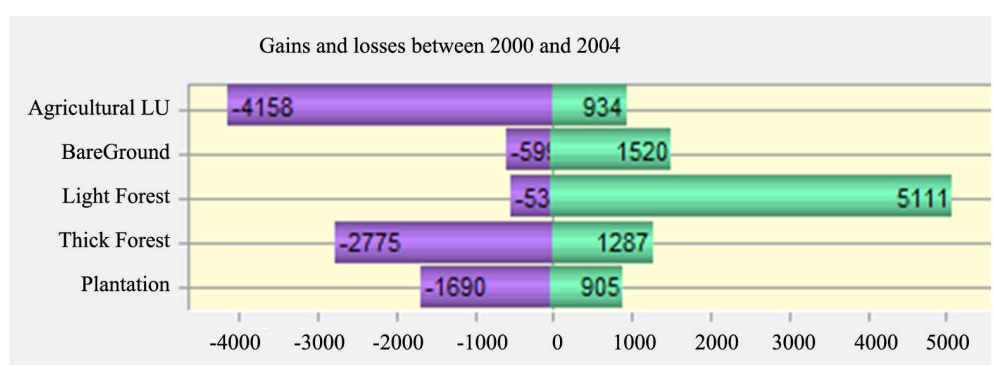

Figure 6. Gain and losses (Ha) in land use/land cover from 2000 to 2014.

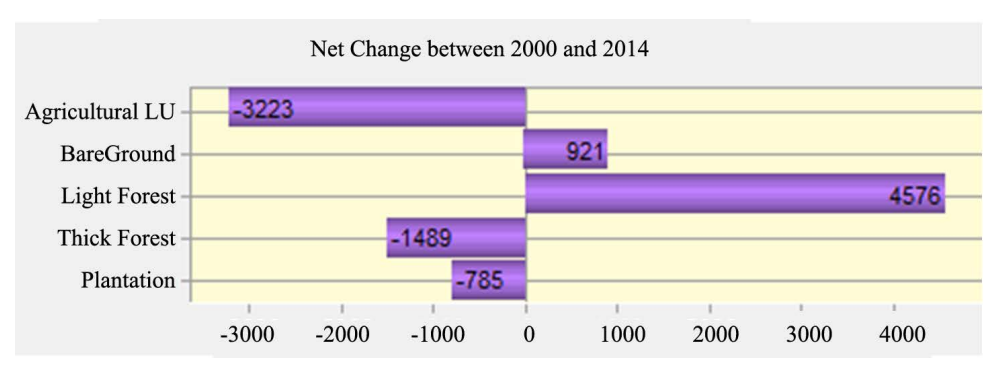

Figure 7. Net changes (Ha) in land use/land cover at Gambari Forest Reserve from 1984 to 2014.

maps. Both the absolute percentage increments between the two years and relative percentage increments from 2000 were calculated. Negative symbols in the statistics indicated a loss of surface [81].

The plantation, thick forest and agricultural land use suffered losses in both absolute and relative terms between 2000 and 2014. In absolute term, 10.69\% of the thick forest and 5.63\% of the plantation were lost during the fourteen-year period. These losses translated into increase in the amount of bare ground and light forest. Figure 10 shows the transition map between 2000 and 2014. 


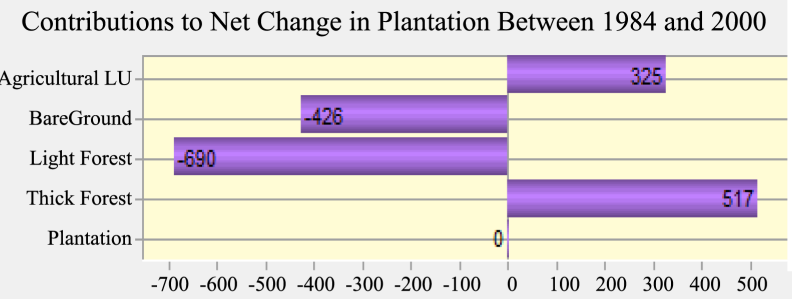

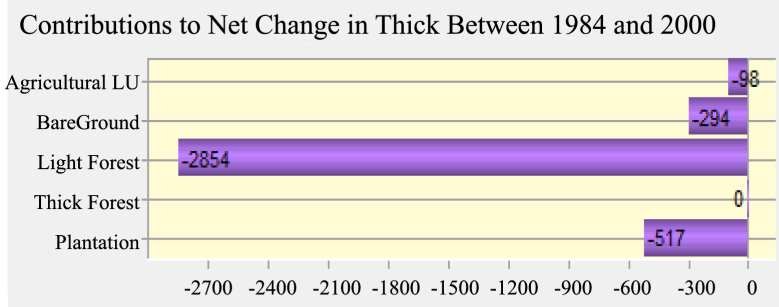

Contributions to Net Change in BareGround Between 1984 and 2000

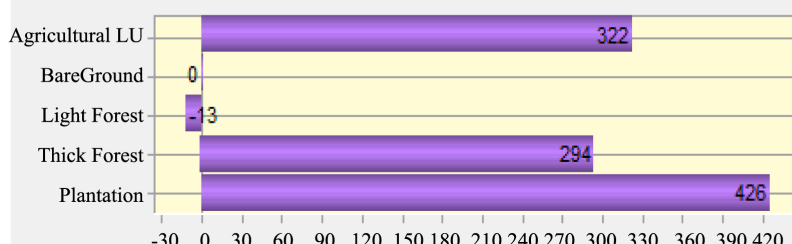

Contributions to Net Change in Light Forest Between 1984 and 2000

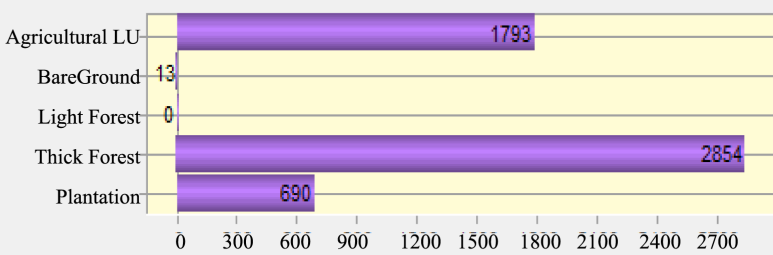

Contributions to Net Change in Agricultural LU Between 1984 and 2000

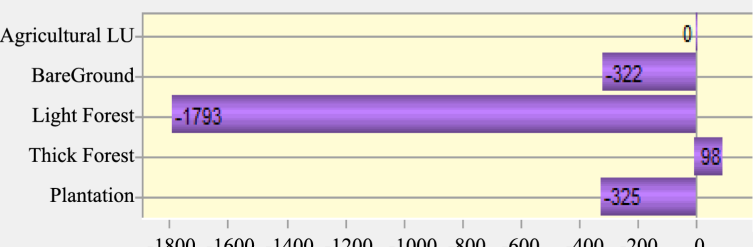

Figure 8. Contributions (Ha) to net changes (1984-2000).

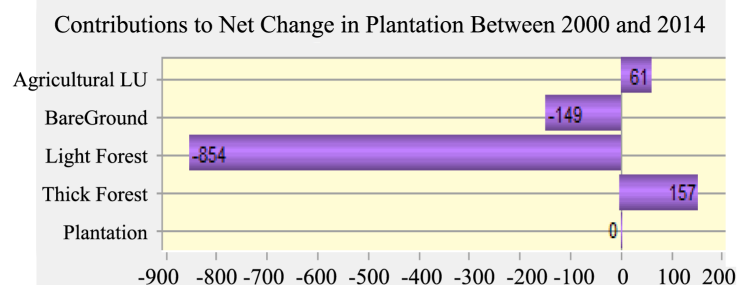

Contributions to Net Change in Thick Between 2000 and 2014

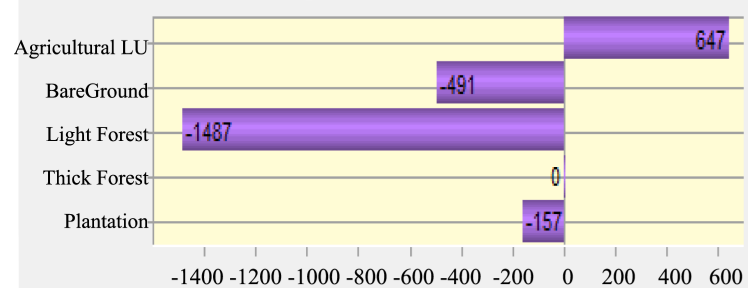

Contributions to Net Change in BareGround Between 2000 and 2014

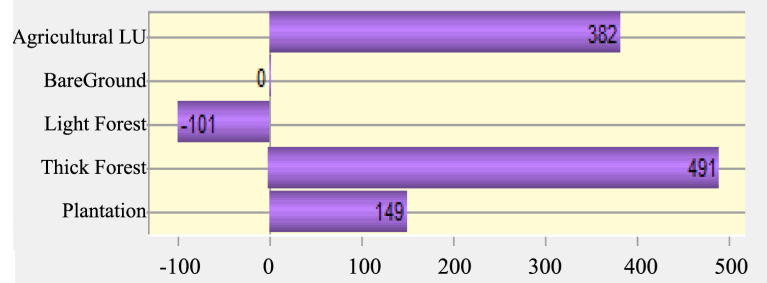

Contributions to Net Change in Light Forest Between 2000 and 2014

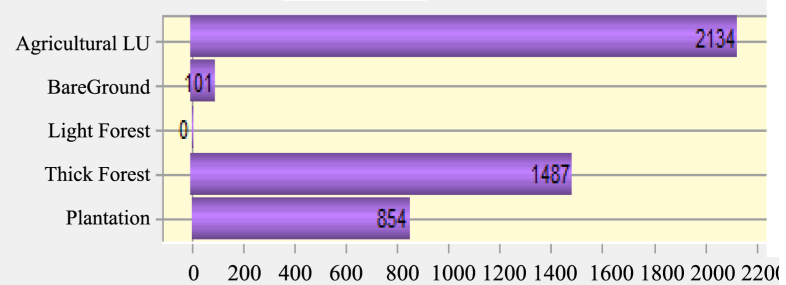

Contributions to Net Change in Agricultural LU Between 2000 and 2014

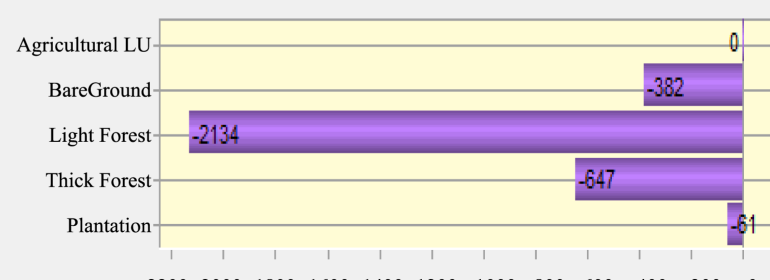

$-2200-2000-1800-1600-1400-1200-1000 \quad-800 \quad-600 \quad-400 \quad-200 \quad 0$

Figure 9. Contributions (Ha) to net changes (2000-2014). 


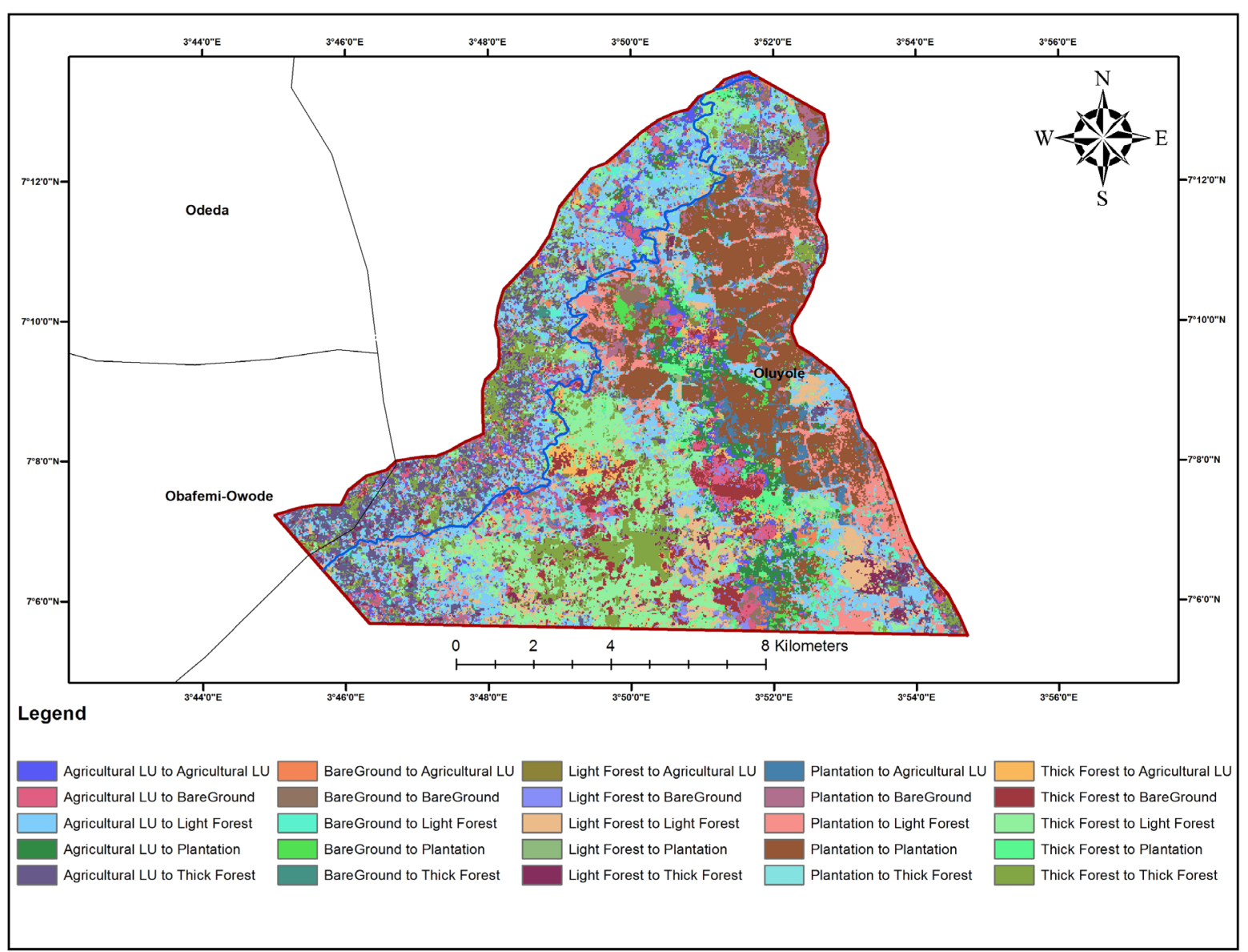

Figure 10. Land use transition between 2000 and 2014.

\subsection{Land Cover Change Prediction with Land Change Modeller}

The analysis of past changes or LULC distributions with regard to spatial explanatory variables enables to assess the degree to which locations might likely change in the future. Markov analysis was performed for the multi-temporal land cover images of 1984-2014 including predicting for 2044 as shown in Figure 11. Results of the Markov models are focused predominantly on providing the knowledge of how much, where, what type of land use changes has occurred from 2014 to 2044. The prediction of the future scenarios in land use change in the study area suggested a continued degradation of the plantation and thick forest resulting in more degraded lands. It should be noted that vegetation loss and degradation could reduce precipitation infiltration and runoff regulation in the forest reserve and promotes soil erosion.

\section{Conclusion}

This study made use of Landsat TM imageries of 1984 and 2000, and OLI/TIRS of 2014 to identify, classify, assess and interpret changes in the Gambari Forest Reserve for the year 1984, 2000 and 2014 respectively. The land cover categories and their changes for these years were generated and analysed in the GIS environment using ArcGIS 10.0 and the land use/land cover scenarios for 30 years from 2014 to 2044 was performed using Markov analysis in Idrisi. The result shows that the thick forest and plantation of exotic tree species i.e. teak and gmelina were fast declining due to several anthropogenic activities such as illegal felling of trees for timber, fuelwood and farming. The degradation can be attributed to the pressure of urbanization, poor management of the forest reserve and increasing human activities in the area. Future prediction showed an almost complete absence of thick forest in the area with increase decline in the plantation, which can be very dangerous for biodiversity, and sustainability of the forest resources. The study have shown the versatility of remote sensing and 


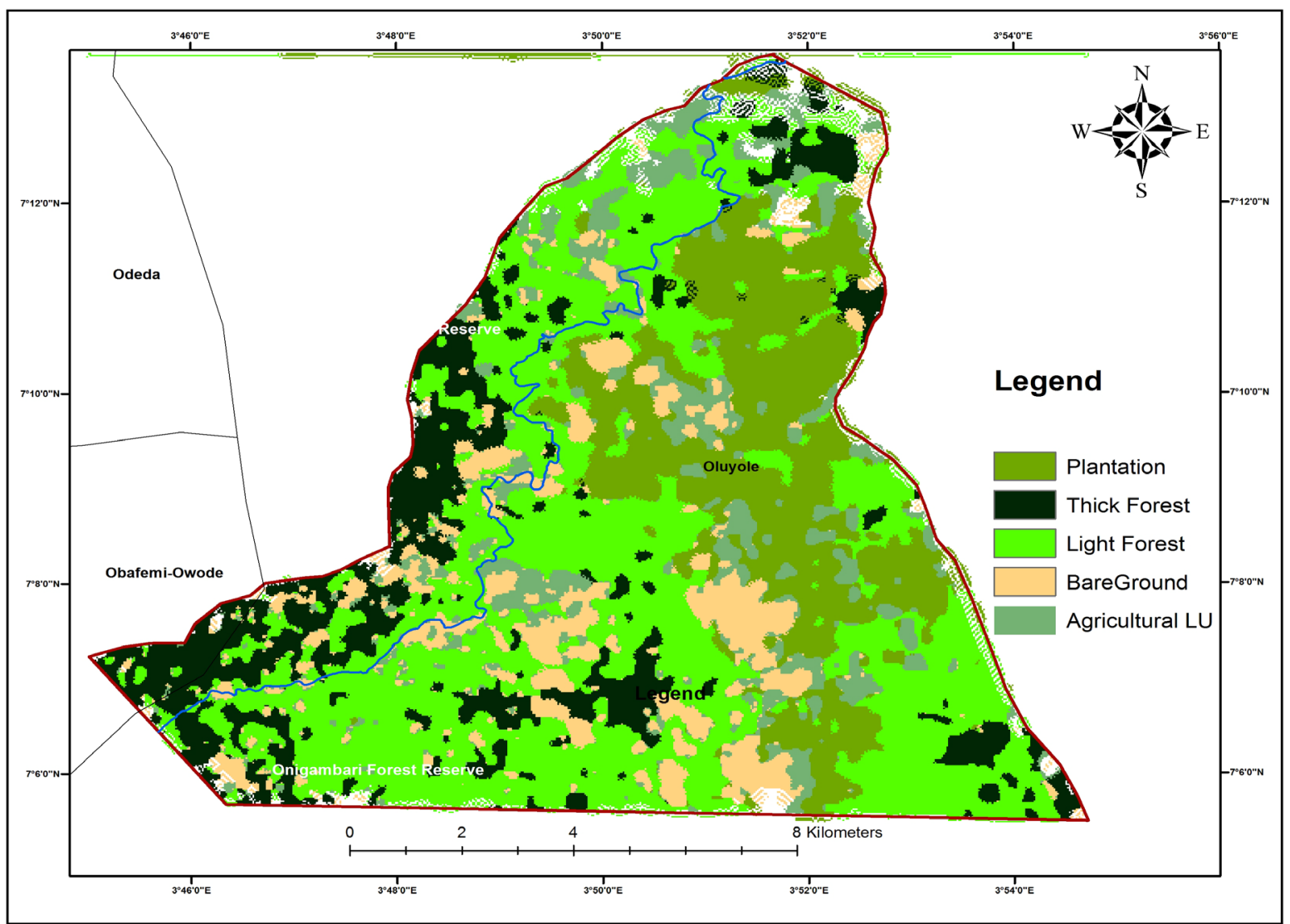

Figure 11. Land use scenario for 2044.

GIS in mapping and monitoring the dynamics of land use/land cover of the study area and provide a useful background for identifying the hot spot and prepare appropriate conservation and management programmes for ecological sustainability.

\section{Acknowledgements}

The authors wish to thank several contributors for the supply of data, reading the manuscript and making useful contributions.

\section{References}

[1] Ojo, L.O. and Ola-Adams, B.A. (1996) Measurement of Tree Diversity in the Nigerian Rainforest. Biodiversity and Conservation, 5, 1253-1270. http://dx.doi.org/10.1007/BF00051575

[2] Ihenyen, J., Mensah, J.K. and Okoegwale, E.E. (2010) Tree/Shrubs Species Diversity of Ehor Forest Reserve in Uhunmwode Local Government Area of Edo State, Nigeria. Researcher, 2, 37-49.

[3] FAO (1999) State of the World's Forests, 1999. 3rd Edition. Food and Agriculture Organization of the United Nations, Rome. http://www.fao.org/forestry/FO/SOFO/SOFO99/sofo99-e.stm or http://www.fao.org/forestry/en/

[4] FEPA (1992) Guidelines and Standards for Environmental Pollution Control in Nigeria. Federal Environmental Protection, Agency Press, Lagos.

[5] Akinnagbe, A. (2001) Stem Diameter Distribution Model in Akure Forest Reserve, Nigeria. M. Tech Thesis submitted to the Department of Forestry and Wood Technology, Federal University of Technology, Akure, 14-56.

[6] Akingbogun, A.A., Kosoko, O.S.O.A. and Aborisade, D.K. (2012) Remote Sensing and GIS Application for Forest Reserve Degradation Prediction and Monitoring. First FIG Young Surveyors Conference Knowing to Create the Future, Rome, 4-5 May 2012, 1-27.

[7] Akande, J.A. (2002) Wood Biomass Form. In: Abu, J.E., Oni, P.I. and Popoola, L., Eds., Forestry and Challenges of 
Sustainable Livelihood, Proceedings of 28th Annual Conference of the Forest Association of Nigeria, Akure.

[8] SER/IUCN (2006) Ecological Restoration_A Means of Conserving Biodiversity and Sustaining Livelihoods. A Call to Action by the Ecological Restoration Joint Working Group of SER International and the IUCN Commission on Ecosystem Management.

http://www.ser.org/resources/resources-detail-view/ecological-restoration-a-means-of-conserving-biodiversity-and-sust aining-livelihoods

[9] Oguntala, A.B. (1981) The Dynamics of Tree Population in Gambari Forest Reserve, Nigeria. Nig. Jour. of For., 2, 5-9.

[10] FAO (2010) Global Forest Resources Assessment (2005 and 2010) and the State of the World's Forests. Rome.

[11] Fasola, T.R. (2007) Controlling the Advancement of Savanna into Southwestern Nigeria. Zonas Áridas, 11, $251-259$.

[12] Zhang, W.J. (2012) Did Eucalyptus Contribute to Environment Degradation? Implications from a Dispute on Causes of Severe Drought in Yunnan and Guizhou, China. Environmental Skeptics and Critics, 1, 34-38.

[13] Adedeji, O.H. (2001) Tropical Forest Dereservation and Degradation: Challenges to Stabilizing Soil Resources and Sustainable Development in Nigeria. Knowledge Review. A Multidisciplinary Journal of National Association for the Advancement of Knowledge, 4, 114-126.

[14] Käyhkö, N., Fagerholm, N., Asseid, B.S. and Mzee, A.J. (2011) Dynamic Land Use and Land Cover Changes and Their Effect on Forest Resources in a Coastal Village of Matemwe, Zanzibar, Tanzania. Land Use Policy, 28, $26-37$. http://dx.doi.org/10.1016/j.landusepol.2010.04.006

[15] Hartter, J., Lucas, C., Gaughan, A.E. and Lizama Aranda, L. (2008) Detecting Tropical Dry Forest Succession in a Shifting Cultivation Mosaic of the Yucatan Peninsula, Mexico. Applied Geography, 28, 134-149. http://dx.doi.org/10.1016/j.apgeog.2007.07.013

[16] Mulongoy, K.J. and Gidda, S.B. (2008) The Value of Nature: Ecological, Economic, Cultural and Social Benefits of Protected Areas. Secretariat of the Convention on Biological Diversity, Montreal, $30 \mathrm{p}$.

[17] Mittermeier, R.A., Robles Gil, P., Hoffmann, M., Pilgrim, J., Brooks, T., Mittermeier, C.G., Lamoreux, J. and Da Fonseca, G.A. (2004) Hotspots Revisited: Earth’s Biologically Richest and Most Endangered Terrestrial Ecoregions. CEMEX, Mexico City.

[18] Adejuwon, J.O. (1967) Vegetation Mapping on a Topographical Scale in the Forest Areas of Western Nigeria. Nigerian Geographical Journal, 10, 29-42.

[19] Oyinloye, R.O., Agbo, B.F. and Aliyu, Z.O. (2004) Land Use/Land Cover Mapping in Osun State Using NigeriaSAT1Data.

[20] Lemmens, M. (2001) Geo-Information from LiDAR. GIM International, July 2003.

[21] Hansen, M.C., Roy, D.P., Lindquist, E., Adusei, B., Justice, C.O. and Altstatt, A. (2008) A Method for Integrating MODIS and Landsat Data for Systematic Monitoring of Forest Cover and Change in the Congo Basin. Remote Sensing of Environment, 112, 2495-2513. http://dx.doi.org/10.1016/j.rse.2007.11.012

[22] Gómez, C., White, J.C. and Wulder, M.A. (2011) Characterizing the State and Processes of Change in a Dynamic Forest Environment Using Hierarchical Spatio-Temporal Segmentation. Science of the Total Environment, 115, 1665-1679. http://dx.doi.org/10.1016/j.rse.2011.02.025

[23] Rahman, M.R. and Saha, S.K. (2009) Spatial Dynamics of Cropland and Cropping Pattern Change Analysis Using Landsat TM and IRS P6 LISS III Satellite Images with GIS. Geo-Spatial Information Science, 12, 123-134. http://dx.doi.org/10.1007/s11806-009-0249-2

[24] Lupo, F., Linderman, M., Vanacker, V., Bartholomé, E. and Lambin, E.F. (2007) Categorization of Land-Cover Change Processes Based on Phenological Indicators Extracted from Time Series of Vegetation Index Data. International Journal of Remote Sensing, 28, 2469-2483. http://dx.doi.org/10.1080/01431160600921943

[25] Achard, F., Eva, H., Stibig, H.J., Mayaux, P., Gallego, J., Richards, T. and Malingreau, J.P. (2002) Determination of Deforestation Rates of the World's Humid Tropical Forests. Science, 297, 999-1002. http://dx.doi.org/10.1126/science.1070656

[26] Lillesland, M.T., Kiefer, W.R. and Dupman, W.J. (2004) Remote Sensing and Image Interpretation. 5th Edition, John Wiley and Sons, Inc., New York.

[27] Dodge, R.L. and Congalton, R.G., Eds. (2013) Meeting Environmental Challenges with Remote Sensing Imagery. American Geosciences Institute, Alexandria.

[28] Aplin, P. (2005) Remote Sensing: Ecology. Progress in Physical Geography, 29, 104-113. http://dx.doi.org/10.1191/030913305pp437pr

[29] Jensen, J.R. (2000) Remote Sensing of the Environment: An Earth Resource Perspective. 2nd Edition, Prentice-Hall, Saddle River. 
[30] Oñate-Valdivieso F. and Sendra J.B. (2010) Application of GIS and Remote Sensing Techniques in Generation of Land Use Scenarios for Hydrological Modelling. Journal of Hydrology, 395, 256-263. http://dx.doi.org/10.1016/j.jhydrol.2010.10.033

[31] IGBP (1999) Land-Use and Land-Cover Change (LUCC) Implementation Strategy. IGBP Report No. 48/IHDP Report No 10. Stockholm (Sweden): International Geosphere-Biosphere Programme (IGBP), International Human Dimension Programme on Global Environmental Change (IHDP).

[32] Mejebi, D.J.J. (2008) An Assessment of the Various Types of Land Degradation within the River Kubanni Basin of Zaria, Nigeria. In: Bisong, F.E., Ed., Geography and the Millennium Development Goals: Translating Vision into Reality, Ultimate Index Books Publishers, Calabar, 64-70.

[33] Roy, H.G., Fox, D.M. and Emsellem, K. (2014) Predicting Land Cover Change in a Mediterranean Catchment at Different Time Scales. In: Murgante, B., Misra, S., Rocha, A.M.A.C., Torre, C., Rocha, J.G., Falcão, M.I., et al., Eds., Proceedings of the 14th International Conference, Part IV, Guimarães, 30 June-3 July 2014, 315-330.

[34] Salami, A.T. (1999) Vegetation Dynamics on the Fringes of Lowland Humid Tropical Rainforest of Southwestern Nigeria an Assessment of Environmental Change with Air Photos and Landsat TM. International Journal of Remote Sensing, 20, 1169-1181. http://dx.doi.org/10.1080/014311699212920

[35] EEA (2007) Land-Use Scenarios for Europe: Qualitative and Quantitative Analysis on a European Scale. EEA Technical Report 9/2007, European Environmental Agency (EEA), Luxembourg.

[36] Miller, J. and Rogan, J. (2007) Using GIS and Remote Sensing for Ecological Mapping and Monitoring. In: Mesev, V., Ed., Integration of GIS and Remote Sensing, John Wiley and Sons, Ltd., 233-268.

[37] McDermid, G.J., Franklin, S.E. and LeDrew, E.F. (2005) Remote Sensing for Large-Area Habitat Mapping. Progress in Physical Geography, 29, 449-474. http://dx.doi.org/10.1191/0309133305pp455ra

[38] Schulz, J.J., Cayuela, C., Echeverria, C., Salas, J. and Rey Benayas, J.M. (2010) Monitoring Land Cover Change of the Dryland Forest Landscape of Central Chile (1975-2008). Applied Geography, 30, 436-447. http://dx.doi.org/10.1016/j.apgeog.2009.12.003

[39] Carmelo, R.F., Giuseppe, M. and Maurizio, P. (2012) Land Cover Classification and Change-Detection Analysis Using Multi-Temporal Remote Sensed Imagery and Landscape Metrics. European Journal of Remote Sensing, 45, 1-18.

[40] Kerr, J.T. and Ostrovsky, M. (2003) From Space to Species: Ecological Applications for Remote Sensing. Trends in Ecology and Evolution, 18, 299-305. http://dx.doi.org/10.1016/S0169-5347(03)00071-5

[41] Loveland, T.R. and Dwyer, J.L. (2012) Landsat: Building a Strong Future. Remote Sensing of Environment, 122, $22-29$. http://dx.doi.org/10.1016/j.rse.2011.09.022

[42] Pellikka, P.K.E., Lotjonen, M., Sijander, M. and Lens, L. (2009) Airborne Remote Sensing of Spatiotemporal Change (1955-2004) in Indigenous and Exotic Forest Cover in the Taita Hills, Kenya. International Journal of Applied Earth Observation and Geoinformation, 11, 221-232. http://dx.doi.org/10.1016/j.jag.2009.02.002

[43] Jennings, M.D. (2000) Gap Analysis: Concepts, Methods, and Recent Results. Landscape Ecology 15, 5-20. http://dx.doi.org/10.1023/A:1008184408300

[44] Rogan, J. and Miller, J. (2006) Integrating GIS and Remote Sensing for Mapping Forest Disturbance and Change. In: Wulder, M.A. and Franklin, S.E., Eds., Understanding Forest Disturbance and Spatial Pattern: Remote Sensing and GIS Approaches, CRC Press-Taylor and Francis, Boca Raton, 133-171. http://dx.doi.org/10.1201/9781420005189.ch6

[45] Adeniyi, P.O and Omojola, A. (1999) Landuse/Landcover Change Evaluation in Sokoto-Rima Basin of North-Western Nigeria on Archival Remote Sensing and GIS Techniques. Journal of African Association of Remote Sensing of the Environment (AARSE), 1, 142-146.

[46] Ezeomedo, I.C. (2006) Change Analysis of Land Use/Land Cover of Yola Metropolis to Aid Planning for a Sustainable Development. B.Tech. Project Submitted to the Department of Surveying and Geoinformatics, Federal (ModdiboAdama), University of Technology Yola, Nigeria.

[47] Clark Labs (2010) Modelling REDD Baselines using IDRISI’s Land Change Modeller. IDRISI Focus Paper http://www.clarklabs.org/about/Focus-Paper-Modeling-REDD-Baselines-IDRISI-Land-Change-Modeler.cfm

[48] Working Plan (1954) Working Plan for the Gambari Plantation (Vol. 1) for the Period of 1 April 1953-31 March 1964.

[49] Akinnifesi, F.K. and Akinsanmi, F.A. (1995) Linear Equations for Estimating the Merchantable Wood Volume of Gmelina arborea in Southwest Nigeria. Journal of Tropical Forest Science, 7, 391-397.

[50] Larinde, S.L. and Olasupo, O.O. (2011) Socio-Economic Importance of Fuelwood Production in Gambari Forest Reserve Area, Oyo State, Nigeria. Journal of Agriculture and Social Research (JASR), 11.

[51] Oyeniyi, O.L. and Aweto, A.O. (1986) Effects of Teak Planting on Alfisols Topsoil in Southwestern Nigeria. Singapore Journal of Tropical Geography, 7, 145-151. http://dx.doi.org/10.1111/j.1467-9493.1986.tb00178.x 
[52] FAO-UNESCO (1977) FAO-UNESCO Soil Map of the World, Vol. VI. Africa. UNESCO, Paris, 299.

[53] Jones, M.J. and Wild, A. (1975) Soils of the West African Savanna, the Maintenance and Improvement of Their Fertility. Commonwealth Agricultural Bureau, 246.

[54] Aborisade, K.D. and Aweto, A.O. (1990) Effects of Exotic Tree Plantations of Teak (Tectona grandis) and Gmelina (Gmelina arborea) on a Forest Soil in South-Western Nigeria. Soil Use and Management, 6, 43-45. http://dx.doi.org/10.1111/j.1475-2743.1990.tb00796.x

[55] Kaufman, Y.J. (1989) The Atmospheric Effect on Remote Sensing and Its Corrections. In: Asrar, G., Ed., Theory and Applications of Optical Remote Sensing, Wiley-Interscience, New York, 336-428.

[56] Mussie, O. (2011) Bias in Land Cover Change Estimates Due to Misregistration. International Journal of Remote Sensing, 21, 3553-3560.

[57] El Hajj, M., Bégué, A., Lafrance, B., Hagolle, O., Dedieu, G. and Rumeau, M. (2008) Relative Radiometric Normalization and Atmospheric Correction of a SPOT 5 Time Series. Sensors, 8, 2774-2791. http://dx.doi.org/10.3390/s8042774

[58] Sabins, F.F. (1996) Remote Sensing Principles and Interpretation. 3rd Edition, W.H. Freeman and Company, New York.

[59] Jensen, J.R. (2005) Introductory Digital Image Processing: A Remote Sensing Perspective. 3rd Edition, Prentice Hall Series in Geographic Information Science.

[60] Tseng, D.C., Tseng, H.T. and Chien, C.L. (2008) Automatic Cloud Removal from Multi-Temporal SPOT Images. Applied Mathematics and Computation, 205, 584-600. http://dx.doi.org/10.1016/j.amc.2008.05.050

[61] Jensen, J.R. (2007) Remote Sensing of the Environment: An Earth Resource Perspective. 2nd Edition, Pearson Prentice Hall, Upper Saddle River.

[62] Weng, Q. (2002) Land Use Change Analysis in the Zhujiang Delta of China Using Satellite Remote Sensing, GIS and Stochastic Modelling. Journal of Environmental Management, 64, 273-284. http://dx.doi.org/10.1006/jema.2001.0509

[63] Magidi, J.T. (2010) Spatio-Temporal Dynamics in Land Use and Habitat Fragmentation in the Sandveld, South Africa. MSc Thesis, Department of Biodiversity and Conservation Biology, University of the Western Cape, Western Cape.

[64] Lillesland, M.T. and Kiefer, R. (1999) Remote Sensing and Image Interpretation. 4th Edition, John Wiley and Sons, Inc., New York.

[65] Wu, Q., Li, H., Wang, R., Paulussen, J., Hec, Y., Wang, M., Wang, B. and Wang, Z. (2006) Monitoring and Predicting Land Use Change in Beijing Using Remote Sensing and GIS. Landscape and Urban Planning 78, 322-333. http://dx.doi.org/10.1016/j.landurbplan.2005.10.002

[66] Bekalo, M.T. (2009) Spatial Metrics and Landsat Data for Urban Land Use Change Detection: Case of Addis Ababa, Ethiopia.

[67] Kleeschulte, S and Büttner, G. (2006) European Land Cover Mapping-The CORINE Experience. North American Land Cover Summit, AAG Special Issue, Chap. 4, 31-44.

[68] Ramachandra, T.V. and Kumar, U. (2004) Geographic Resources Decision Support System for Land Use, Land Cover Dynamics Analysis. Proceedings of the FOSS/GRASS Users Conference, Bangkok, 12-14 September 2004.

[69] Eastman, J.R. (2006) IDRISI Andes Guide to GIS and Image Processing, Worcester, Clark Labs.

[70] IDRISI (2006) IDRISI Andes: Guide to GIS and Image Processing. Clark Labs, Clark University, Worcester. http://www.cartografia.cl/download/manuales/idrisi_andes.pdf

[71] Mishra, M., Mishra, K., Subudhi, A. and Phil, M. (2011) Urban Sprawl Mapping and Land Use Change Analysis Using Remote Sensing and GIS: Case Study of Bhubaneswar City, Orissa. Proceedings of the Geo-Spatial World Forum, Hyderabad, 18-21 January 2011.

[72] Deng, J.S., Wang, K., Hong, Y. and Qi, J.G. (2009) Spatio-Temporal Dynamics and Evolution of Land Use Change and Landscape Pattern in Response to Rapid Urbanization. Landscape and Urban Planning, 92, 187-198. http://dx.doi.org/10.1016/j.landurbplan.2009.05.001

[73] Odindi, J., Mhangara, P. and Kakembo, V. (2012) Remote Sensing Land-Cover Change in Port Elizabeth during South Africa's Democratic Transition. South African Journal of Science, 108, 1-7. http://dx.doi.org/10.4102/sajs.v108i5/6.886

[74] Bangamwabo, V.M. (2010). Spatial and Temporal Extent of Land Degradation in a Communal Landscape of KwaZulu-Natal, South Africa. MSc Thesis, University of KwaZulu-Natal, South Africa.

[75] Mhangara, P., Kakembo, V. and Lim, K.J. (2012) Soil Erosion Risk Assessment of the Keiskamma Catchment, South Africa Using GIS and Remote Sensing. Environmental Earth Sciences, 65, 2087-2102. http://dx.doi.org/10.1007/s12665-011-1190-x 
[76] Fabio, P. (2007) Change Detection Algorithms: State of the Art; Earth Observation Laboratory. Tor Vergata University, Rome.

[77] Arsanjani, J.J, Helbich, M., Kainz, W. and Boloorani, A. D. (2013) Integration of Logistic Regression, Markov Chain and Cellular Automata Models to Simulate Urban Expansion. International Journal of Applied Earth Observation and Geoinformation, 21, 265-275.

[78] Eastman, J.R. (2012) IDRISI Selva Tutorial. IDRISI Production, Clark Labs-Clark University, Worcester, 45.

[79] Veldkamp, A. and Lambin, E.F. (2001) Predicting Land-Use Change. Agriculture, Ecosystems and Environment, 85, 1-6. http://dx.doi.org/10.1016/S0167-8809(01)00199-2

[80] Iacono, M., Levinson, D., El-Geneidy, A and Wasfi, R. (2012) A Markov Chain Model of Land Use Change in the Twin Cities, 1958-2005. http://nexus.umn.edu/papers/MarkovLU.pdf

[81] Melendez-Pastor, I., Hernández, E.I., Navarro-Pedreño, J. and Gómez, I. (2014) Socioeconomic Factors Influencing Land Cover Changes in Rural Areas: The Case of the Sierra de Albarracín (Spain). Applied Geography, 52, 34-45. http://dx.doi.org/10.1016/j.apgeog.2014.04.013

[82] Clark Labs (2013) IDRISI Spotlight: Earth Trends Modeller. Clark labs. Clark University, Worcester.

[83] Pontius Jr., R.G. and Pacheco, P. (2004) Calibration and Validation of a Model of Forest Disturbance in the Western Ghats, India 1920-1990. GeoJournal, 61, 325-334. http://dx.doi.org/10.1007/s10708-004-5049-5

[84] Kio, P.R.O. (1992) Forest Conservation Strategies for Tropical Africa. University of Ibadan, Nigeria, 4. (Unpublished)

[85] FORMECU (1998) Assessment of Vegetation and Land Use Changes in Nigeria, between 1976/78 and 1993/95. Unpublished Report by Geomatics International Inc., and Beak International Inc., 36.

[86] Islam, M.S. and Ahmed, R. (2011) Land Use Change Prediction in Dhaka City Using GIS Aided Markov Chain Modelling. Journal of Life and Earth Science, 6, 81-89.

[87] Serra, P., Pons, X. and Saurí, D. (2003) Post-Classification Change Detection with Data from Different Sensors. 